Cornell Law Library

Scholarship@Cornell Law: A Digital Repository

Cornell Law Faculty Publications

Faculty Scholarship

$8-1972$

\title{
Regulatory Structure and Regulatory Performance: A Critique of the Ash Council Report
}

Roger C. Cramton

Cornell Law School, rcc10@cornell.edu

Follow this and additional works at: http://scholarship.law.cornell.edu/facpub

Part of the Administrative Law Commons

\section{Recommended Citation}

Cramton, Roger C., "Regulatory Structure and Regulatory Performance: A Critique of the Ash Council Report" (1972). Cornell Law Faculty Publications. Paper 942.

http://scholarship.law.cornell.edu/facpub/942

This Article is brought to you for free and open access by the Faculty Scholarship at Scholarship@Cornell Law: A Digital Repository. It has been accepted for inclusion in Cornell Law Faculty Publications by an authorized administrator of Scholarship@Cornell Law: A Digital Repository. For more information, please contact jmp8@cornell.edu. 
To shift our concentration from matters of internal organization to those of the political setting moves us toward a long-needed reintegration between professional analysis of regulatory administration and the liveliest currents of general empirical political theory. Among the latter currents, one of the most promising consists of Theodore J. Lowi's categorization of policies and related political processes into distributive, regulatory, constituency, and redistributive types. According to Lowi, each of these types carries with it a distinctive pattern of political activity. In the legislative arena, for example, he finds that regulatory measures are much more amended on the floor of both House and Senate than those of the other types - and that this is irrespective of whether the President at the time is known as "strong" or "weak." One of the many intriguing possible implications of Lowi's study is that we could purposely design policy structures to produce desired patterns of politics, or avoid undesired patterns: regulatory approaches to policy will activate Congress; distributive approaches to policy dampen public involvement. Contra much conventional wisdom (which has tended to think in President versus Congress terms), presidential ascendancy in policy development is not universal in fact and is not a panacea in principle. Active regulatory development is likely to be associated with both strong presidential leadership and significant congressional contributions to the shaping of policy.

The politics of policy structures, which Lowi's conceptualization opens up for us, leads us to a more fundamental levei of analysis, one that encourages us to relate regulatory questions to the larger political arena in novel ways. And if we can break down the isolation of regulatory studies from general political analysis, we will have taken a significant step toward strengthening the contribution of academic political science to important governmental problems.

Michael D. Reagan

University of California at Riverside

\title{
Regulatory structure And Regulatory PERFORMANCE:
} A CRITIQUE OF THE ASH COUNCIL REPORT

\author{
Roger C. Cramton, Chairman, Administrative Conference of the United States
}

On February 11, 1971, President Nixon released a report of his Advisory Council on Execu-

This article was originally prepared for delivery at the Spring 1971 meeting of the Section on Antitrust Law of the American Bar Association. It is reproduced here with the permission of the Section on Antitrust Law. tive Organization (the Ash Council) entitled "A New Regulatory Framework - A Report on Selected Independent Regulatory Agencies."1 The report recommends far-reaching changes in the structure and regulatory responsibilities of six independent regulatory agencies - the Civil Aeronautics Board, Federal Maritime Commission, 
Federal Power Commission, Federal Trade Commission, Interstate Commerce Commission, and the Securities and Exchange Commission - and a reduction in the size of the Federal Communications Commission. The President's accompanying statement urged vigorous public discussion of the Ash Council's Report and early submission of comments and criticism from interested public and private groups.

The purpose of this article is to consider the basic premise of the Ash Council Report - that the structure of a regulatory agency has a profound effect on regulatory performance. This premise underlies three general proposals for reform which the report advances for broad application in these agencies:

1. The substitution of a single adminsitrator for the multi-headed board or commission.

2. Dramatic changes in the agencies' internal decisional process.

3. Judicial review by a new, nonconstitutional, specialized court, rather than the regular courts of appeal, or, in the case of the Interstate Commerce Commission, a special three-judge district court. Each of these proposals will be briefly examined.

\section{Regulatory Structure: The Single Administrator}

The Ash Council recommends that the independent regulatory commissions in the transportation, power, securities, and consumer protection fields be transformed into executive agencies headed by single administrators responsible to the President. The substitution of a single administrator for the multi-headed collegial body is the kingpin in the Ash Council's whole approach; it is presented almost as a universal panacea for the solution of the problems of the independent regulatory agencies.

The report recounts the advantages of a single administrator at great length. These advantages are framed in terms of relatively abstract concepts such as "accountability," "responsiveness," "efficiency," "good management," "expedition," and the like. We are told that these virtues, and other good things such as improved personnel, will flow from the substitution of a single administrator for the multi-headed collegial body. All of this is somewhat reminiscent of Lewis Carroll's remark that "It must be so because you have repeated it three times!"

In the view of the Ash Council, the single administrator is godlike, and the multi-headed collegial body suffers from a multitude of sins. The proposition is not supported by empirical evidence, but is asserted as a self-evident, universally applicable truth. I am skeptical of an assertion that seems over broad and that must be taken on faith.

The case that is made for the single administrator has a certain surface plausibility. There are areas, such as the current development of environmental standards by the Environmental Protection Agency, in which a single administrator reporting directly to the President seems likely to do a more effective job than a multi-headed board. On the other hand, we know that single-minded, strong men running very important government operations are susceptible of great drawbacks. One could refer, in terms of responsiveness as against rigidity, to such agencies as the Selective Service System under Lewis B. Hershey or the FBI under J. Edgar Hoover.

I am not referring at this point to the quality of regulatory performance, but only to the question of accountability and responsiveness, to which the Ash Council gives great emphasis. Perhaps a more crucial question is how the structure of an agency affects the performance of its regulatory tasks. I am doubtful whether there is any simple relationship, for reasons elaborated below.

\section{Criteria for Regulatory Performance}

In order to determine the relationship between structure and performance, one must first have a consistent notion of what constitutes good regulatory performance. What are the criteria for judging regulatory performance? The Ash Council Report gives us very little help on this question. It tends to suggest two criteria: (1) expedition in formulating policy and completing proceedings; and (2) responsiveness of the agency, particularly to signals from the Executive. While important, it is hard to accept these criteria as the sole or most important ones.

Expedition, of course, is fine if agencies are doing what you want them to do. Some critics believe that the combination of all of the transportation agencies in a single agency - surely desirable on efficiency grounds - would lead to a dominance of current Interstate Commerce Commission regulatory attitudes and would provide the opportunity, now lacking because of intermodal competition which the separate agencies are unable to control, to create an effective cartel in the 
transportation industries. Under this view, substitution of a single administrator for transportation would be disastrous unless accompanied by legislative revision of transportation policy, including substantial deregulation.

Criteria for evaluating regulatory performance, it is evident, are needed in order to assess proposed changes in regulation. Until the goals against which regulation is to be measured are determined, it is impossible to determine whether or not those goals will be achieved by a structural change from a multi-headed body to a single administrator. ${ }^{2}$

The historical contest between Congress and the President for control or isolation of some of these regulatory functions needs also to be mentioned at this point. Congress has sought over the years to insulate certain regulatory functions from Executive control, perhaps enhancing at the same time the control of congressional committees over those same functions and activities. Organizational theory has no good answer for this struggle between the Executive and Congress; it is a question of politics and government which the electorate should decide. ${ }^{3}$

\section{Lack of Empirical Evidence}

A second comment is that casual experience does not support an unqualified preference for the single administrator. One can look around the federal government today and find good and bad examples of each type of organization, depending upon what your own criteria for evaluation are. In other words, there is a lack of a factual basis for the Ash Council's conclusion that single-headed agencies perform better. It is something you have to arrive at by a leap of faith, by an intuitive jump. The Ash Council Report is a failure as an empirical document.

And yet many of these questions are susceptible to examination. It is my impression, for example, that the Veterans Administration - which is an agency headed by a single administrator - has not obtained markedly better personnel than the Securities and Exchange Commission, a multi-headed collegial body. Nor is it evident to me that the Comptroller of the Currency - again a single administrator - has done a more effective job of banking regulation than the Federal Reserve Board or the Home Loan Bank Board, both of which are multi-headed agencies.

Further instances are easily found. Is there any evidence, for example, that the regulatory functions of the Departments of Agriculture and
Interior are performed better than those of the independent commissions? Our preoccupation with the regulatory functions of the independent agencies has blinded us to the fact that there may be lots of bodies buried in obscure regulatory corners in the executive departments. There are other factors which are just as important or more important than regulatory structure. ${ }^{4}$

\section{Other Plausible Explanations of Regulatory Defects}

Two other plausible explanations of why regulation has defects must be explored before structure can be given the decisive role assigned to it by the Ash Council. One alternative theory is that many of the problems of regulation are inherent in the regulatory task itself, and especially when the regulatory task is one of giving out benefits to an industry which has constant contact with the dispensing agency. If a small group of regulated firms have great interest in regulatory activities, while the general public is only peripherally or marginally affected, it is inevitable that the information, concern, and political clout of the regulated firms will be effectively communicated to the agencies through our political process. Our regulatory agencies, regardless of organization, tend to be highly responsive to the political pressures that are brought to bear upon them. The general public, which brings its latent power to bear only in situations of failure or catastrophe that arouse general concern, has much less interest in influencing regulatory decisions. Regulators - well aware of the episodic character of public interest in regulation - lean over backwards to avoid failures of service, dramatic accidents, and the like. The pressures of incumbent firms, intent upon protecting their franchised positions against new competitors or new technology, are often in the same direction; they tend to be as cautious in approach and as fearful of calamity as the regulators. It is this community of interest between regulators and regulated that is often referred to under the rubric of "captive agencies."

A second alternative theory is that the observed defects of regulation are largely the results of inadequate, outmoded, or vague substantive policies. Railroad regulation was initially designed to restrain the economic power of railroads in an era when there were few, if any, competing forms of transportation. ${ }^{6}$ Motor carrier regulation stems from a period when competition was viewed as undesirable, even for an industry with little or no economies of scale. ${ }^{7}$ Aviation regulation, also 
reflecting the New Deal era's distrust of market forces, seeks to promote air service without regard to its effects on other modes. ${ }^{8}$ Separate agencies administer regulatory policies for different modes; and subsidies to some modes in the construction and maintenance of facilities (especially to water and air carriers) are administered by other agencies without regard to the effects on unsubsidized transportation service. In short, there is no national transportation policy but only a melange of confused and contradictory protective, promotional, and regulatory policies.

While transportation has served here as a convenient example, other regulatory fields are also characterized by divided authority, outmoded policies, and vague standards. ${ }^{9}$ The confusion of agencies and policies in the energy field, for example, is widely recognized. It is no accident that those agencies with the simplest and most widely accepted missions - such as the protection of the integrity of the securities markets by the Securities and Exchange Commission - are commonly viewed as turning in the best performance. The key to regulatory performance, under this theory, is to be found not in agency structure but in the opportunities or pitfalls inherent in the substantive task of regulation.

It is my personal view that the two alternative hypotheses outlined above are, in combination, more plausible explanations of regulátory defects than the Ash Council's undue emphasis on structure. While structure is important, other considerations are vastly more important.

\section{Agency Decisional Process}

In addition to the substitution of single administrators for most of the present boards and commissions, the Ash Council Report proposes a dramatic short circuiting of the decisional stages now followed by most agencies. The initial decisions of hearing examiners in adjudicatory cases would become final agency decisions unless the single administrator, within a fixed period of $\mathbf{3 0}$ days, reversed or modified the initial decision because it was inconsistent with agency policy. Only a limited opportunity for postponing a final decision by remanding a case for further hearing would be provided; and it would be subject to a further time limit of 30-45 days.

The ultimate objective, of course, is that of expediting the decision of adjudicatory cases. In addition, limiting the administrator's ability to evolve policy by means of case-by-case adjudication would presumably force administrators to formulate regulatory policies in general rulemaking proceedings. Delegating greater decisional authority to hearing examiners would have the further effect of increasing their status, responsibility, and - hopefully - performance. Administrators, freed from a heavy workload of routine controversies, could direct their attention to major policy issues.

While these objectives are laudable ones, it seems likely that the Ash Council proposal is more procrustean than workable. The choice between rule making and adjudication as a method of formulating policy is more complicated than the Ash Council indicated. ${ }^{10}$ And a number of agencies already have gone very far in delegating decisional authority in routine cases to hearing examiners or to employee boards. ${ }^{11}$ Further steps along this line might achieve most of the objectives sought by this aspect of the Ash Council Report.

A major factor, not fully considered by the Ash Council, is the effect of its shortened decisional process on rights of party participation. The fixed period of review by the administrator - a review presumably limited to questions of general policy - would deprive the parties of any participation during the final decisional stage. Once the hearing examiner came down with his initial decision, there would be no exceptions, no briefs, no oral arguments. The administrator himself will have only 30 days to master - by some mysterious process, and without any further assistance from the parties - the complexities of the case and to reverse, modify, or affirm the decision.

The consequences of this procedure would be unfortunate. Briefs, exceptions, and oral arguments before an agency crystallize issues, illuminate the case, and help the agency reach a wiser and more informed decision. They also provide interested persons with an effective opportunity to educate the ultimate deciders.

Moreover, in many administrative cases, the issues develop and change as the case goes along. It is not unusual for the decision at the agency level to focus on matters that were not emphasized by the hearing examiner. In these situations, an opportunity to submit briefs and arguments when the case is before the agency for final decision may be an essential ingredient of fairness. ${ }^{12}$ 


\section{Specialized Reviewing Court}

The Ash Council Report proposes the creation of a specialized reviewing court, composed of judges without life tenure, to review the decisions of the transportation, power, and securities agencies. Once again, the proposal pursues laudable goals - here the desire to relieve the federal courts of an unnecessary burden and to improve the review function.

An initial problem with the proposal is that it would not make a dent in the heavy caseload of the federal courts of appeals. The new specialized reviewing court would have jurisdiction of cases which constitute less than four per cent of the present workload of the courts of appeals - a miniscule decrease. ${ }^{13}$ Other categories of cases, especially labor and social security cases, would need to be added in order to provide a specialized administrative court of review with a caseload that would relieve the courts of appeals of a substantial burden.

Moreover, administrative review cases involving regulatory action are fairly interesting. They enliven what is otherwise becoming a rather drab appetite of criminal appeals - which constitute about one-half of the cases that the United States courts of appeals now hear. Federal appellate courts will become specialized courts of criminal appeals if other cases are withdrawn from their jurisdiction.

Further, any reconsideration of federal appellate jurisdiction raises questions of priorities. Why should administrative appeals from such agencies be the cases that are pruned away? These cases involve substantial issues of federal law to which the courts of appeals have contributed a great deal of understanding. There are other classes of cases, such as diversity litigation or the tremendous burden of habeas corpus petitions involving repetitive examination of criminal issues that already have been tried in state court proceedings, that are much more deserving candidates for exclusion from the federal courts.

Wholly apart from these workload considerations, the creation of specialized courts raises complicated problems concerning their role, personnel, and the like. The strongest argument for a specialized court can be made in areas like labor, tax, and trade - areas which cut across the whole economy rather than concentrate on a particular industry. Several years ago the American Bar Association proposed the creation of "administra- tive courts" to exercise final administrative authority in these areas. ${ }^{14}$ The Ash Council departs from these earlier proposals both as to subject matter (labor, tax, and trade are areas in which the Ash Report does not apply its "administrative court" proposal) and as to the nature of the court (appellate rather than trial court as in the earlier ABA proposals).

There are dangers in the application of a specialized administrative court - whether trial or appellate in nature - to one or a few regulated industries. $^{15}$ Where the agency is in the business of handing out extremely valuable perquisites, grants, licenses, and the like, which have enormous effects on the economic fortunes of firms in the industry, the dangers of partiality and departures from adjudicatory fairness are enlarged. One can be sure that industry representatives are going to be constantly battling for appointment of specialists who know about and sympathize with their problems. The administrative court approach is most properly applicable in areas where adjudicative enforcement functions have a moral quality, and where decisions turn on determinations of past facts, which are required to be made on the basis of a record. In situations of this kind, it may make sense to use a specialized tribunal of high quality - particularly at the trial stage.

An independent adjudicatory tribunal, cutting across industry lines, also surmounts the separation-of-functions problem, which has been emphasized with respect to the Federal Trade Commission by former FTC Commissioner Elman. ${ }^{16}$ There is a legitimate difference of opinion concerning the significance of the separation-offunctions problem in administrative agencies. Whatever one may think of the combination of adjudicatory and prosecutory functions as a general problem, the objection has the strongest force in those agencies, such as the National Labor Relations Board and the Federal Trade Commission, where adjudications typically involve nonrecurring past events and charges of antisocial conduct. Economic regulation that looks to the future, that is largely policy oriented, in which a wide range of alternatives are considered by regulatory bodies, has a very different character; and in such proceedings the separation-offunctions problem is considerably reduced. The Administrative Procedure Act recognizes this distinction by exempting rate making and initial licensing from its separation-of-functions requirements. This distinction between types of pro- 
ceedings was implicitly recognized in placing the prosecutory function in the unfair labor practice field in an office independent from the National Labor Relations Board. Current demands for a similar separation with respect to the Federal Trade Commission have not yet been acceded to.

The Ash Council proposal does not improve the separation-of-functions problem in the trade field. In fact, it worsens existing difficulties, because, instead of a group of five people who can exercise a moderating influence upon one another and who may not be intimately involved in the earlier stages of the case, the Ash Council would substitute a single administrator in the trade practices area. Since the administrator would be responsible for the staff, responsible for the prosecutorial decisions, and then also responsible for the final decision, affected persons are likely to be even more fearful than now that the adjudication of their cases will be by a prosecutor with a closed mind. ${ }^{17}$

\section{Conclusion}

While I am critical of the Ash Council proposals, my criticism should not be taken as a defense of the status quo. Many things need to be done to improve the structure, organization, and procedures of our federal agencies. In some areas, such as transportation, radical surgery may be required, including experimentation with a single administrator. ${ }^{18}$

The Ash Council has performed a service in pointing the finger at important problems and suggesting the need for change. The particular mechanisms which the Ash Council has recommended, however, should be not adopted. Inquiry into needed changes in the regulatory process should not be confined merely to structural or organizational matters. There is an even greater need for fundamental reexamination of the substantive premises and policies of regulation.

\section{Notes}

1. The President's Advisory Council on Executive Organization, A New Regulatory Framework - Report on Selected Independent Regulatory Agencies (1971), hereinafter referred to as the Ash Council Report.

2. See Roger G. Noll, Reforming Regulation: An Evaluation of the Ash Council Report (Washington, D.C.: The Brooking Institution, Brookings Studies in the Regulation of Economic Activity, 1971), p. 3.

3. See, e.g., G. Robinson, "On Reorganizing the Independent Regulatory Agencies, "Virginia Law Review, Vol.
57 (1971), which ably summarizes the extensive literature dealing with the organization and effectiveness of independent regulatory agencies. The Administrative Conference of the United States in its "Views" on the Ash Council Report, concluded that:

"The status of the regulatory commissions raises complex issues of political theory and practice that cannot be evaluated solely in terms of managerial efficiency. Those issues may be grouped for convenience under the headings of independence and collegiality (or multimembership as distinct from a single chief officer). Independence - a matter of degree and in part a state of mind - has both positive and negative aspects. Detachment from external influences in making particularized decisions is generally considered to be desirable. Diffusion of responsibility that may produce hesitant or uncoordinated governmental policies is generally regarded as undesirable. Whether or not an agency is independent in these respects, however, is not exclusively determined by whether the agency is located within or outside the Executive Branch. Persuasive evidence has not yet been adduced to show that the independent commissions, to a significantly greater degree than executive agencies, have achieved the desired detachment or produced the weak or discordant policies.

"As for collegiality, consideration must be given to values inherent in an official body that is not dominated by a single will. Among those values are diversity of background and experience, an open decisional process, and a tendency toward moderation in policy.

"Further study, including empirical examination of the relative effectiveness of independent commissions and executive agencies performing comparable regulatory functions, is required before it may be concluded that either form is generally the more desirable."

Administrative Conference of the United States, 1970-71 Annual Report, p. 60, hereinafter cited as Annual Report.

4. The Administrative Conference "Views" on the Ash Council Report similarly concluded that:

"The deficiencies of regulation by collegial bodies cannot be attributed solely or primarily to faulty structure; the same deficiencies may be observed in regulatory agencies headed by single administrators responsible to the President. The view that substitution of a single administrator would solve regulatory problems is simplistic, unsupported by empirical data, and overlooks other plausible explanations of regulatory ills, especially the inherent difficulties of regulating activities having a vast impact on the economy and the absence in many areas of legislative definition of regulatory goals. Structural alteration in itself offers only possibilities for limited improvement in regulatory performance; it is no substitute for a thorough and critical reexamination of the statutory framework in which the agencies operate and of the policies they are directed to carry out."

Annual Report, p. 61. 
5. See, e.g., R. Noll, "The Economics and Politics of Regulation," Vinginia Law Review, Vol. 57 (1971):

“... The performance of regulated industries falls short of a reasonable, attainable social objective because the regulators operate under a different definition of the public interest than that held by society generally.

“... The process of regulation, regardless of how or where it is performed, is inherently biased in favor of regulated firms, even if regulators have the best of intentions."

For recent attempts to develop a theory of regulation, see G. Stigler, "The Theory of Economic Regulation," Bell Journal of Economics and Management Science, Vol. 1 (1970), pp. 3-21; and Roger Noll, supra, note 2.

6. See, e.g., J. Meyer, M. Peck, J. Stenason, and C. Zwick, The Economics of Competition in the Transportation Industries, Harvard Economic Studies No. 109 (1959); J. Nelson, Railroad Transportation and Public Policy (1959); R. Fellmuth, The Interstate Commerce Omission (1970).

7. The legislative rationales for the regulation of trucking are spelled out in W.K. Jones, Cases on Regulated Industries, pp. $487-499$ (1967). See also, J. Meyer, supra, note 6, pp. 215-222, 263; and R. Fellmuth, supra, note 6, pp. 119-135.

8. See, e.g., R. Caves, Air Transport and Its Regulators (1962); W. Jones, supra, note 7, pp. 736-738; W. Jordan, Airline Regulation in America (1970).

9. See, e.g., H. Friendly, The Federal Administrative Agencies (1962); and Noll, supra, note 5:

"The new regulation replaces the rule of law with uncertainty and continual bargaining over the bounds of legitimate behavior. ...

"A number of defects of regulation are related to the vagueness of the regulatory mandate: unequal treatment of like cases; additional uncertainty introduced by regulatory inconsistency; elaborate legal procedures, since each case is, in essence, a new law; and a much heavier caseload, since a prior adverse decision does not sufficiently deter the raising of the same issue."

10. See, e. $\rightarrow \mathrm{G}$. Robinson, "The Making of Administrative Policy: Another Look at Rulemaking and Adjudication and Administrative Procedure Reform," University of Pennsylvania Law Review, Vol. 118 (1970), p. 485.

11. See, $e .2 \rightarrow \mathrm{J}$. Freedman, "Review Boards in the Administrative Process," University of Pennsylvania Law Review, Vol. 117 (1969), p. 546; "Note, Intermediate Appeal Boards for Administrative Agencies," Harvard Law Review, Vol. 81 (1968), p. 1325; and C. Auerbach, "Scope of Authority of Federal Administrative Agencies to Delegate Decision-Making to Hearing Examiners," Minnesota Law Review, Vol. 48 (1964), p. 823.

12. The Administrative Conference "Views" on the Ash Council Report concluded that:

"Limitation of party participation to the period prior to an initial decision is undesirable as well as unfair. Wise decisions in complex regulatory cases are largely dependent upon the illuminating and sharpening of issues which are most suitably provided by the parties, including agency staff who have functioned as parties in the particular proceeding. Parties who are denied participation in the final decisionmaking through public procedures may be tempted to influence the agency through ex parte means.

"Other procedural devices, such as development of policy through rulemaking rather than adjudication, provision that decisions by hearing examiners are final unless the agency determines that review is desirable, reduction of interlocutory appeals, and use of employee review boards to relieve agency heads of routine cases, have expedited the decisional process, enhanced the status of hearing examiner, prevented repetitious consideration of routine matters, and allowed agency heads to concentrate on important questions of policy. The often imperative need to improve agency functioning calls for sustained effort to encourage procedural advances like those suggested above." (See Administrative Conference Recommendation No. 6 - Delegation of final decisional authority subject to discretionary review by the agency.)

Annual Report, pp. 62-63.

13. See N. Nathanson, "The Administrative Court Proposal of the President's Advisory Council on Executive Reorganization," Vinginia Law Review, Vol. 57 (1971). The Administrative Conference "Views" on the Ash Council Report stated that:

"The proposed new tribunal would not relieve the regular courts of a substantial burden; less than three percent of the cases making up the current workload of the present reviewing courts would be affected. It is highly doubtful whether such a small caseload justifies the creation of a new tribunal. Moreover, if the courts of appeals must be relieved of some of their present workload, it would be a questionable choice of priorities to relieve them of regulatory cases rather than of other categories of cases, such as diversity litigation, which do not involve significant questions of federal law. Finally, a new tribunal with review authority over the decisions of only a small minority of agencies cannot be expected to make the contributions to uniformity in administrative law which the Ash Council sees as one of the advantages of its establishment."

14. See U.S. Commission on Organization of the Executive Branch of Government, Legal Services and Procedures, (1955), pp. 84-88; American Bar Association Report, Vol. 81 (1956), pp. 378-379 (Proceedings of the House of Delegates); and Minor, "The Administrative Court: Variations on a Theme," Obio State Law Journal, Vol. 19 (1958), p. 380.

15. The Administrative Conference "Views" on the Ash Council Report stated that:

"There is a danger that a narrowly specialized reviewing court, concerned with the actions of only a few industries, might become or give the appearance of becoming identified with the agency or industry point of view. Appointments to such a court could 
pose a special problem, because, while of vital importance to the regulated industry, they would be less subject to broad professional and public scrutiny than appointments to the courts of appeals."

16. See P. Elman, "The Regulatory Process: A Personal View," BNA Antitrust and Trade Reg. Report No. 475, D1-D5 (1970); P. Elman, "Administrative Reform of the Federal Trade Commission," Georgia Law Journal, Vol. 59 (1971), p. 777.

17. The Administrative Conference "Views" on the Ash Council Report similarly stated that:

"One traditional ground of attack on the independent regulatory commission, particularly applied to enforcement functions of such agencies as the Federal Trade Commission, is the charge that unfairness to respondents may result when agency heads exercise prosecutory and rulemaking functions along with that of adjudication. Whatever the merits of this charge as a general matter, the concentration of regulatory authority in a single administrator increases at least the appearance, though not necessarily the reality, of a merger of inconsistent functions.

Annual Report, p. 62.
18. Thus the Administrative Conference "Views" stated that:

"While the Conference is not persuaded that the proposed form of agency organization - a single administrator responsible to the President - is generally superior to the collegial form, it may offer advantages in specific areas of regulation, particularly where vigorous departures from existing regulatory techniques are called for. Whether an existing regulatory framework should or should not be continued is largely dependent upon substantive rather than organizational considerations. If a decision were made, for example, to eliminate various restraints that now affect the various modes of transportation, the remaining regulatory controls might practicably be vested in a new agency structured differently from those now in existence. With respect to the other regulatory agencies, a major realignment of regulatory responsibilities is not proposed and a convincing case has not as yet been made for replacement of the collegial form with a single administrator."

Annual Report, p. 61.

\title{
Recycling the regulatory agencies
}

\author{
John E, Moore, University of California, Santa Barbara
}

There is a curious tendency, most recently exemplified in the Ash Council Report, ${ }^{1}$ to distinguish the shortcomings of the regulatory process from those of the political system of which it is a part, ascribe those shortcomings to the structural or procedural characteristics associated with the regulatory process, and then fail to distinguish the variety of functions performed by different regulatory agencies and the varied environments in which those functions are performed.

This article proceeds from a rather different set of premises:

- much of the malaise associated with the regulatory process can be attributed to the same forces that are responsible for increasing disaffection from the political system generally

- responses based almost exclusively upon structural or procedural reforms are more likely to compound than to reduce this disaffection, since they continue to confuse substance with process

- as the Administrative Conference observed in its "Views" on the Ash Council Report, "whether an existing regulatory framework should or should not be continued is largely dependent upon substantive rather than organizational considerations"2

- these substantive considerations vary with the nature of the policy area, regulatory function, and political environment

- while changes in structure and procedure may improve the capacity of the "regulatory process" as a whole to cope with the varied problems it confronts, such changes should be near the bottom rather than at the top of our agenda.

The least we can do to mark the end of an era is to fashion a new metaphor. "Recycling" implies a deliberate provision for invigorating and redefining the goals of the regulatory agencies, as contrasted with (1) the pessimistic metaphysical pathos of the "life cycle" metaphor that despairs of change in the absence of a jarring crisis in the regulated activity, or overwhelming evidence of senility in the regulatory agency, and (2) the excessive optimism of those who would have the regulatory agencies operating at an unremittingly feverish pitch. 